\title{
ANALISIS PERBANDINGAN MODEL ALTMAN, MODEL SPRINGATE, DAN MODEL ZMIJEWSKI DALAM MEMPREDIKSI KEBANGKRUTAN BANK SYARIAH DI INDONESIA
}

\author{
Diyah Santi Hariyani \\ Agung Sujianto \\ Universitas PGRI Madiun \\ agung.sujianto@yahoo.com
}

\begin{abstract}
The purpose of this research to provide empirical evidence that the Model Altman , Springate, and Zmijewski is the most appropriate model for predicting bankruptcy Islamic Bank in Indonesia. The population in this study are all Islamic banks listed on the Indonesia Stock Exchange. This study uses secondary data from the financial statements of Islamic banks in 2010-2014. Testing the hypothesis in this study using normality test, homogeneity test, and one way ANOVA test ( different test). The results showed that Springate model is the most appropriate model to predict the Islamic banks in Indonesia with an accuracy of $38.00 \%$, then Model Zmijewski with $28.00 \%$ accuracy rate and Altman with an accuracy of $0.00 \%$.
\end{abstract}

Keywords : Altman Z-Score Model, Springate S-Score Model, Zmijewski X-Score Model.

\section{PENDAHULUAN}

Latar Belakang

Perkembangan zaman yang

diikuti dengan perkembangan teknologi dan perubahan siklus ekonomi menyebabkan dunia usaha juga terus mengalami perubahan. Perubahan ini berdampak pada persaingan ketat yang dialami semua kalangan pelaku dalam dunia bisnis. Perusahaan diharapkan tidak hanya mampu beradaptasi dengan keadaan, tetapi juga dapat menjaga kelangsungan hidup perusahaan di tengah perubahan yang terus terjadi (Sinambela, 2009).

Pada dasarnya perusahaan yang go public memanfaatkan keberadaan pasar modal sebagai sarana untuk mendapatkan sumber dana atau alternatif pembiayaan. Adanya pasar modal dapat dijadikan sebagai alat untuk merefleksikan kinerja dan kondisi keuangan perusahaan. Pasar akan merespon positif melalui peningkatan harga saham perusahaan jika kondisi keuangan dan kinerja perusahaan bagus. Para investor dan kreditur sebelum menanamkan dananya pada suatu perusahaan akan selalu melihat terlebih dahulu kondisi keuangan perusahaan tersebut. Oleh karena itu, analisis dan prediksi atas kondisi keuangan suatu perusahaan sangat penting (Atmini, 2005).

Kondisi perekonomian di Indonesia yang masih belum menentu mengakibatkan tingginya risiko suatu perusahaan untuk mengalami kesulitan keuangan atau bahkan kebangkrutan. Kesalahan prediksi terhadap kelangsungan operasi suatu perusahaan di masa yang akan datang dapat berakibat fatal yaitu kehilangan pendapatan atau investasi yang telah ditanamkan pada suatu perusahaan. Oleh karena 
itu, pentingnya suatu model prediksi kebangkrutan suatu perusahaan menjadi hal yang sangat dibutuhkan oleh berbagai pihak seperti pemberi pinjaman, investor, pemerintah, akuntan, dan manajemen (Zu'amah, 2005).

Selain itu fenomena rupiah yang terus melemah juga menjadi kekhawatiran oleh berbagai pihak. Jika rupiah terus melemah ke angka Rp 15.000, diperkirakan lima perbankan nasional akan kolaps. Memburuknya nilai tukar rupiah terhadap mata uang dolar Amerika Serikat (AS) membuat industri perbankan Indonesia siaga dari kemungkinan terburuk itu. Ini serupa dengan krisis ekonomi yang menerjang Indonesia pada akhir 1998. Saat itu puluhan bank 'tumbang' akibat rupiah yang terus melambung dan menyentuh Rp 18.000 per dolar AS. Deputi Komisioner Pengawasan Perbankan Otoritas Jasa Keuangan (OJK) Irwan Lubis mengungkapkan pihaknya telah melakukan langkah antisipatif dengan memanggil manajemen perbankan terkait depresiasi tersebut.

Penelitian tentang kebangkrutan suatu perusahaan telah banyak dilakukan di Indonesia. Akan tetapi kurangnya penelitian tentang Bank Syariah serta perbandingan model prediksi kebangkrutan yang tepat menjadi menarik bagi peneliti untuk meneliti "Perbandingan Model Altman, Model Springate, dan Model Zmijewski Dalam Memprediksi Kebangkrutan Bank Syariah di Indonesia".

\section{Tujuan Penelitian}

Berdasarkan latar belakang diatas, penelitian ini bertujuan: untuk memberikan bukti empiris bahwa model Altman, Springate, dan
Zmijewski adalah model yang paling tepat dalam memprediksi kebangkrutan Bank Syariah di Indonesia.

\section{TEORI PENUNJANG}

Model Altman

Model Altman (1968) menggunakan metode Multiple Discriminant Analysis dengan lima jenis rasio keuangan yaitu working capital to total asset, retained earning to total asset, earning before interest and taxes to total asset, market value of equity to book value of total debts, dan sales to total asset. Sampai saat ini, Altman ZScore masih lebih banyak digunakan oleh para peneliti, praktisi, serta para akademis di bidang akuntansi dibandingkan model prediksi lainnya. Hasil penelitian yang dikembangkan Altman, yaitu:

$Z=1.2 \mathrm{Z1}+1.4 \mathrm{Z2}+3.3 \mathrm{Z3}+0.6$

$\mathrm{Z4}+0.999 \mathrm{Z5}$

\section{Keterangan:}

$\mathrm{Z1}=$ working capital/total asset

$\mathrm{Z} 2$ = retained earnings/total asset

$\mathrm{Z3}=$ earnings before taxes/total asset

$\mathrm{Z4}$ = book value of equity/book value of debt

$\mathrm{Z5}=$ sales/total asset

Model yang dikembangkan

oleh Altman ini mengalami suatu revisi. Revisi yang dilakukan oleh Altman merupakan penyesuaian yang dilakukan agar model prediksi kebangkrutan ini tidak hanya untuk perusahaan manufaktur yang go publik melainkan juga dapat diaplikasikan untuk perusahaanperusahaan di sektor swasta. Model yang lama mengalami perubahan pada salah satu variabel yang digunakan. 
$Z^{\prime}=0.0717 \mathrm{Z1}+0.874 \mathrm{Z2}+3.107 \mathrm{Z3}$

$+0.420 \mathrm{Z4}+0.988 \mathrm{Z5}$

Keterangan:

$\mathrm{Z} 1=$ working capital/total asset

$\mathrm{Z} 2$ = retained earnings/total asset

$\mathrm{Z3}=$ earnings before taxes/total asset

$\mathrm{Z4}=$ book value of equity/book value of debt

$\mathrm{Z5}=$ sales/total asset Hasil akhir berupa nilai ZScore dari masing-masing perusahaan akan dikelompokkan sesuai dengan standar nilai kritis yang ditetapkan oleh Altman, yaitu (Cahyono, 2013) :

a) Jika nilai Z-Score lebih besar dari 2,99 maka perusahaan masuk ke safe zone, yaitu area dimana perusahaan dikatakan sehat atau tidak bangkrut.

b) Jika nilai Z-Score yang berada diantara 1,01 - 2,99 termasuk pada grey zone, yang berarti perusahaan berada di daerah abu-abu, dimana perusahaan bisa berpotensi perusahaan tidak bangkrut atau bangkrut.

c) Jika nilai Z-Score lebih kecil dari 1,01 berarti perusahaan masuk ke distres zone, dimana perusahaan tidak sehat atau berpotensi mengalami kebangkrutan.

\section{Model Springate}

Model ini dikembangkan oleh Springate (1978) dengan menggunakan analisis multidiskriminan. Model ini dapat digunakan untuk memprediksi kebangkrutan dengan tingkat keakuratan 92,5\%. Model yang berhasil dikembangkan oleh Springate adalah:

$S=1.03 A+3.07 B+0.66 C+0.4 D$
Keterangan:

$\mathrm{A}=$ working capital/total asset

$\mathrm{B}=$ earnings before taxes/total asset

$\mathrm{C}=$ earnings before taxes / current liabilities

$\mathrm{D}=$ sales/total asset

Hasil akhir berupa nilai Springate dari masing-masing perusahaan akan di kelompokkan sesuai dengan standart nilai kritis yang ditetapkan Springate sebagai berikut:

a) Jika nilai Springate lebih besar dari 0,862 maka perusahaan masuk dalam kategori perusahaan sehat.

b) Jika nilai Springate lebih kecil dari 0,862 maka perusahaan masuk ke dalam kategori perusahaan tidak sehat atau berpotensi sebagai perusahaan bangkrut.

\section{Model Zmijewski}

Model Zmijewski (1984) menggunakan analisis rasio yang mengukur kinerja, leverage, dan likuiditas suatu perusahaan untuk model prediksinya. Zmijewski menggunakan probit analisis yang diterapkan pada 40 perusahaan yang telah bangkrut dan 800 perusahaan yang masih bertahan saat itu. Model yang berhasil dikembangkan yaitu

$X=-4.3-4.5 \times 1+5.7 \times 2-0.004 \times 3$

Keterangan:

$\mathrm{X} 1=\mathrm{ROA}$ (return on asset)

$\mathrm{X} 2=$ Leverage (debt ratio)

$\mathrm{X} 3$ = Likuiditas (current ratio)

Hasil akhir berupa nilai

Zmijewski dari masing-masing perusahaan akan di kelompokkan sesuai dengan standart nilai kritis 
yang ditetapkan Zmijewski sebagai berikut (Romadhona, 2013):

a) Semakin besar nilai Zmijewski (bernilai positif) maka berpotensi dikatakan sebagai perusahaan yang bangkrut.

b) Semakin kecil nilai Zmijewski (bernilai negatif) Jika nilai Springate lebih kecil bernilai negatif maka dikategorikan sebagai perusahaan yang sehat.

\section{METODOLOGI PENELITIAN}

Kinerja keuangan dapat dinyatakan baik apabila perusahaan dapat menutupi biayanya dengan menggunakan pendapatan dari usahanya pada periode tertentu. Kondisi minimal dari kinerja keuangan agar dapat dikatakan baik adalah dimana tingkat pendapatan sama dengan biaya (Break even point) ataupun lebih.
Laporan keuangan yang telah selesai dibuat dapat dijadikan sebagai dasar dalam menilai kinerja keuangan perusahaan selama periode tertentu. Analisis laporan keuangan merupakan salah satunya, yang dapat dipergunakan untuk mengidentifikasi dan memperbaiki permasalahan yang terjadi di perusahaan.

Kerangka pemikiran dalam penelitian ini dapat dilihat di gambar 2.1 yaitu menggunakan laporan keuangan dalam memprediksi kebangkrutan. Laporan Keuangan tersebut kemudian di tabulasi dengan menggunakan model Altman, Springate, dan Zmijewski untuk menentukan score perusahaan tersebut. Setelah mengetahui score masing masing bank syariah tersebut, kemudian dapat dikategorikan apakah Bank Syariah tersebut tergolong sehat, grey area, maupun bangkrut

\section{ANALISA DAN PEMBAHASAN Analisis Deskriptif}

Tabel 1

Statistik Deskriptif Variabel Penelitian

\begin{tabular}{|c|c|c|c|c|c|}
\hline Variabel & $\mathbf{N}$ & Minimum & Maximum & Mean & SD \\
\hline Z-Score & 50 & 1,085 & 5,822 & 2,44612 & 1,078911 \\
\hline S-Score & 50 & 0,713 & 1,989 & 0,90878 & 0,187491 \\
\hline X-Score & 50 & $-33,140$ & 19,669 & $-3,94662$ & 9,597896 \\
\hline
\end{tabular}

Sumber: Data Diolah

Berdasarkan Tabel 1 di atas, dapat dijelaskan beberapa hal berikut:

- Rata-rata Z-Score (Almant) sebesar 2,44612, nilai minimum 1,085 , nilai maksimum sebesar 5,822, dan standar deviasi sebesar 1,078911 dengan jumlah sample 50. Nilai rata-rata Z-Score (Altman) mendekati nilai standar deviasi sebesar 1,078911, dengan demikian penyimpangan data ZScore (Almant) rendah.
- Rata-rata S-Score (Springate) sebesar 0,90878, nilai minimum sebesar 0,713, nilai maksimum sebesar 1,989, dan standar deviasi sebesar 0,187491 dengan jumlah sample 50. Nilai rata-rata S-Score (Springate) mendekati nilai standar deviasi sebesar 0,187491, dengan demikian penyimpangan data S-Score (Springate) rendah.

- Rata-rata X-Score (Zmijewski) sebesar -3,94662, nilai minimum sebesar $-33,140$, nilai maksimum 
sebesar 19,669, dan standar deviasi sebesar 9,597896 dengan jumlah sample 50. Nilai rata-rata X-Score (Zmijewski) mendekati nilai standar deviasi sebesar 9,597896, dengan demikian penyimpangan data X-Score (Zmijewski) rendah

Hasil Analisis Prediksi Kebangkrutan

Hasil Analisis Z-Score (Altman)
Analisis dalam penelitian ini adalah model diskriminan Z-Score. Analisis ini digunakan untuk mengetahui dan menganalisis prediksi kebangkrutan pada perbankan syariah periode 20102014. Berkut ini formulasi Z-Score:

\section{$\mathrm{Z}=1,2 \mathrm{X} 1+1,4 \times 2+3,3 \times 3+0,6 \times 4+$}

\section{$0,999 \times 5$}

Berdasarkan hasil perhitungan dengan menggunakan program excel diperoleh hasil sebagai berikut:

Tabel 2

Hasil Perhitungan Z-Score Periode Tahun 2010-2014 untuk Perbankan Syariah Kategori Sehat, Bangkrut, dan Grey Area

\begin{tabular}{|c|c|c|c|c|c|c|}
\hline \multirow{2}{*}{$\begin{array}{c}\text { Tahun/ } \\
\text { No. }\end{array}$} & \multirow[b]{2}{*}{ Bank } & \multicolumn{5}{|c|}{ Kategori } \\
\hline & & 2010 & 2011 & 2012 & 2013 & 2014 \\
\hline 1 & BMI & Grey Area & Grey Area & Grey Area & Grey Area & Grey Area \\
\hline 2 & BVS & Grey Area & Grey Area & Grey Area & Grey Area & Grey Area \\
\hline 3 & BRIS & Grey Area & Grey Area & Sehat & Grey Area & Grey Area \\
\hline 4 & BJBS & Sehat & Grey Area & Grey Area & Grey Area & Grey Area \\
\hline 5 & BNIS & Grey Area & Grey Area & Sehat & Grey Area & Grey Area \\
\hline 6 & BMS & Sehat & Sehat & Grey Area & Grey Area & Grey Area \\
\hline 7 & BPS & Grey Area & Grey Area & Sehat & Grey Area & Sehat \\
\hline 8 & BSB & Grey Area & Grey Area & Grey Area & Grey Area & Grey Area \\
\hline 9 & BSM & Grey Area & Sehat & Grey Area & Grey Area & Grey Area \\
\hline 10 & BCAS & Sehat & Sehat & Grey Area & Grey Area & Grey Area \\
\hline
\end{tabular}

Sumber : Data Diolah, 2016.

Berdasarkan Tabel 2, perbankan syariah yang pernah masuk dalam kategori prediksi Sehat Tahun 2010-2014 adalah BJBS, BMS, BCAS, BNIS, BSM, BRIS, dan BPS. Dan semua bank pernah mengalami kondisi prediksi Grey Area. Terdapat 3 (tiga) bank yang selalu mengalami prediksi Grey Area Tahun 2010-2014 yaitu BMI, BVS, dan BSB. Dan tidak terdapat bank yang pernah mengalami prediksi Bangkrut Tahun 2010-2014.

\section{Hasil Analisis S-Score (Springate)}

Analisis dalam penelitian ini adalah model diskriminan S-Score. Analisis ini digunakan untuk mengetahui dan menganalisis prediksi kebangkrutan pada perbankan syariah periode 20102014. Berikut ini formulasi S-Score: $\mathrm{S}=1,03 \mathrm{~A}+3,07 \mathrm{~B}+0,66 \mathrm{C}+\mathbf{0 , 4 D}$ Berdasarkan hasil perhItungan dengan menggunakan program excel diperoleh hasil sebagai berikut: 
Tabel 3

Hasil Perhitungan S-Score Periode Tahun 2010-2014 untuk Perbankan Syariah Kategori Sehat dan Bangkrut

\begin{tabular}{|c|l|c|c|c|c|c|}
\hline Tahun/ & & \multicolumn{5}{|c|}{ Kategori } \\
\cline { 4 - 7 } No. & Bank & $\mathbf{2 0 1 0}$ & $\mathbf{2 0 1 1}$ & $\mathbf{2 0 1 2}$ & $\mathbf{2 0 1 3}$ & $\mathbf{2 0 1 4}$ \\
\hline 1 & BMI & Sehat & Sehat & Sehat & Sehat & Bangkrut \\
\hline 2 & BVS & Sehat & Sehat & Sehat & Sehat & Bangkrut \\
\hline 3 & BRIS & Bangkrut & Bangkrut & Bangkrut & Bangkrut & Bangkrut \\
\hline 4 & BJBS & Sehat & Sehat & Sehat & Sehat & Sehat \\
\hline 5 & BNIS & Sehat & Sehat & Sehat & Bangkrut & Sehat \\
\hline 6 & BMS & Bangkrut & Bangkrut & Sehat & Sehat & Bangkrut \\
\hline 7 & BPS & Bangkrut & Sehat & Bangkrut & Bangkrut & Sehat \\
\hline 8 & BSB & Bangkrut & Bangkrut & Bangkrut & Bangkrut & Bangkrut \\
\hline 9 & BSM & Sehat & Sehat & Sehat & Sehat & Sehat \\
\hline 10 & BCAS & Sehat & Sehat & Sehat & Sehat & Sehat \\
\hline
\end{tabular}

Sumber : Data Diolah.

Berdasarkan Tabel 3 perbankan syariah yang pernah masuk dalam kategori prediksi sehat Tahun 2010-2014 adalah BMI, BVS, BJBS, BNIS, BMS, BSM, dan BCAS, sedangkan bank pernah mengalami kondisi prediksi bangkrut adalah BMI, BVS, BRIS, BNIS, BMS, BPS, dan BSB. Terdapat 3 (tiga) bank yang selalu mengalami prediksi sehat Tahun 2010-2014 yaitu BJBS, BSM, dan BCAS, sedangkan ada 2 (dua) bank yang selalu mengalami prediksi bangkrut
Tahun 2010-2014 yaitu BRIS dan BSB.

Hasil Analisis X-Score (Zmijewski)

Analisis dalam penelitian ini adalah model diskriminan X-Score. Analisis ini digunakan untuk mengetahui dan menganalisis prediksi kebangkrutan pada perbankan syariah periode 20102014. Berkut ini formulasi S-Score:

$X=-4,3-4,5 X 1+5,7 X 2-0,004 X 3$

Berdasarkan hasil perhitungan dengan menggunakan program excel diperoleh hasil sebagai berikut: 


\section{Tabel 4}

Hasil Perhitungan X-Score Periode Tahun 2010-2014

untuk Perbankan Syariah Kategori Sehat dan Bangkrut

\begin{tabular}{|c|l|c|c|c|c|c|}
\hline \multirow{2}{*}{$\begin{array}{c}\text { Tahun/ } \\
\text { No. }\end{array}$} & \multirow{2}{*}{ Bank } & \multicolumn{5}{|c|}{ Kategori } \\
\cline { 3 - 7 } & $\mathbf{2 0 1 0}$ & $\mathbf{2 0 1 1}$ & $\mathbf{2 0 1 2}$ & $\mathbf{2 0 1 3}$ & $\mathbf{2 0 1 4}$ \\
\hline 1 & BMI & Sehat & Sehat & Sehat & Sehat & Bangkrut \\
\hline 2 & BVS & Sehat & Sehat & Sehat & Bangkrut & Bangkrut \\
\hline 3 & BRIS & Bangkrut & Bangkrut & Sehat & Sehat & Bangkrut \\
\hline 4 & BJBS & Sehat & Sehat & Sehat & Sehat & Sehat \\
\hline 5 & BNIS & Sehat & Sehat & Sehat & Sehat & Sehat \\
\hline 6 & BMS & Sehat & Sehat & Sehat & Sehat & Sehat \\
\hline 7 & BPS & Bangkrut & Sehat & Sehat & Sehat & Sehat \\
\hline 8 & BSB & Bangkrut & Bangkrut & Sehat & Bangkrut & Bangkrut \\
\hline 9 & BSM & Sehat & Sehat & Sehat & Sehat & Bangkrut \\
\hline 10 & BCAS & Sehat & Sehat & Sehat & Bangkrut & Bangkrut \\
\hline
\end{tabular}

Sumber : Data Diolah.

Berdasarkan Tabel 4 di atas, perbankan syariah yang pernah masuk dalam kategori prediksi sehat Tahun 2010-2014 adalah BMI, BVS, BJBS, BNIS, BMS, BSM, BPS, BSB, BRIS, dan BCAS, sedangkan bank pernah mengalami kondisi prediksi bangkrut adalah BMI, BVS, BRIS, BPS, BSB, BSM, dan BCAS. Terdapat 3 (tiga) bank yang selalu mengalami prediksi sehat Tahun 2010-2014 yaitu BJBS, BNIS, dan BMS. Hasil analisis X-Score (Zmijewski) terlihat bahwa terdapat perbankan syariah yang selalu pernah masuk dalam kategori prediksi sehat Tahun 2010-2014. Hal ini dapat menunjukkan bahwa model X-Score (Zmijewski) untuk prediksi kebangkrutan pada perbankan syariah periode 2010-2014 yang paling realistis dengan kondisi perbankan syariah saat ini

Hasil Analisis Prasyarat Analisis dan Uji Beda (One Way ANOVA) Uji Normalitas

Uji normalitas bertujuan untuk menguji apakah dalam model data variabel mempunyai distribusi normal atau tidak. Model data yang baik adalah memiliki distribusi data normal atau mendekati normal (Ghozali, 2001). Untuk menguji normalitas, dapat menganalisis nilai probabilitasnya. Model data memenuhi asumsi normalitas dengan dasar pengambilan keputusan adalah, jika nilai probabilitas $>0,05$ dan sebaliknya, jika nilai probabilitas $\leq$ 0,05, maka model regresi tidak memenuhi asumsi normalitas.

Hasil uji normalitas dengan Kolmogorov Smirnov Test sbb: 
Tabel 5

Hasil Uji Normalitas dengan Kolmogorov Smirnov Test

\begin{tabular}{|c|c|c|c|}
\hline Variabel & Sig. & Probabilitas & Keterangan \\
\hline Z-Score & 0,247 & 0,05 & Normal \\
\hline S-Score & 0,059 & 0,05 & Normal \\
\hline X-Score & 0,651 & 0,05 & Normal \\
\hline
\end{tabular}

Sumber: Data Diolah.

\begin{abstract}
Berdasarkan hasil uji normalitas dengan Kolmogorov Smirnov Test di atas terlihat bahwa nilai probabilitas $>0,05$, maka dapat disimpulkan bahwa data berdistribusi normal
\end{abstract}

\section{Uji Homogenitas}

Uji homogenitas bertujuan untuk menguji apakah dalam model data variabel mempunyai distribusi homogen atau tidak. Model data yang baik adalah memiliki distribusi data homogen (Ghozali, 2001). Untuk menguji homogenitas, dapat menganalisis nilai probabilitasnya. Model data memenuhi asumsi homogenitas dengan dasar pengambilan keputusan adalah, jika nilai probabilitas > 0,05 dan sebaliknya, jika nilai probabilitas $\leq$ 0,05, maka model regresi tidak memenuhi asumsi homogenitas. Hasil uji normalitas dengan Levene Test sbb:

Tabel 6

Hasil Uji Homogenitas dengan Levene Test

\begin{tabular}{|c|c|c|c|}
\hline Variabel & Sig. & Probabilitas & Keterangan \\
\hline Altman- Springate- Zmijewski & 0,062 & 0,05 & Homogen \\
\hline
\end{tabular}

Sumber: Data Diolah

Berdasarkan hasil Tabel 6 terlihat bahwa nilai probabilitas $=$ $0,062>0,05$, maka model data memenuhi asumsi homogenitas.

\section{Uji One Way ANOVA (Uji Beda)}

Analisis dalam penelitian ini adalah analisis One Way ANOVA.
Analisis ini digunakan untuk mengetahui perbandingan model Altman, Springate, dan Zmijewski dalam memprediksi kebangkrutan Bank Syariah di Indonesia. Dengan taraf nyata $(\alpha)=5 \%=0,05$ dan dari hasil One Way ANOVA Test diperoleh nilai probabilitas $=0,000$. 


\section{Tabel 7}

Hasil One Way ANOVA Test

Berdasarkan Model Altman, Springate, dan Zmijewski

\begin{tabular}{|c|c|c|c|}
\hline Model & F-test & Sig. & Level of Significant \\
\hline Altman- Springate- Zmijewski & 17,897 & 0,000 & 0,05 \\
\hline
\end{tabular}

Sumber: Data Diolah

Berdasarkan hasil Tabel 7 diperoleh nilai probabilitas One Way ANOVA Test $=0,000<$ Level of Significant $=0,05$, maka disimpulkan bahwa terdapat perbedaan ketiga modell yaitu model Altman, Springate, dan Zmijewski dalam memprediksi kebangkrutan Bank Syariah di Indonesia.

Dari hasil One Way ANOVA dapat juga diketahui perbedaan antar sesama model 1 (satu) dibanding dengan model lainnya:

Tabel 8

Hasil Multiple Comparisons One Way ANOVA Test Berdasarkan Model Altman, Springate, dan Zmijewski

Multiple Comparisons

\begin{tabular}{|c|c|c|c|c|c|c|c|}
\hline & \multirow[b]{2}{*}{ (I) Model } & \multirow[b]{2}{*}{ (J) Model } & \multirow{2}{*}{$\begin{array}{c}\text { Mean } \\
\text { Diff erence } \\
(I-J)\end{array}$} & \multirow[b]{2}{*}{ Std. Error } & \multirow[b]{2}{*}{ Sig. } & \multicolumn{2}{|c|}{ 95\% Confidence Interv al } \\
\hline & & & & & & Lower Bound & Upper Bound \\
\hline \multirow[t]{6}{*}{ Tukey HSD } & Z-Score & S-Score & 1,537340 & 1,115460 &, 355 & $-1,10373$ & 4,17841 \\
\hline & & X-Score & $6,392740^{*}$ & 1,115460 & ,000 & 3,75167 & 9,03381 \\
\hline & S-Score & Z-Score & $-1,537340$ & 1,115460 & ,355 & $-4,17841$ & 1,10373 \\
\hline & & X-Score & $4,855400^{*}$ & 1,115460 & ,000 & 2,21433 & 7,49647 \\
\hline & X-Score & Z-Score & $-6,392740^{*}$ & 1,115460 & ,000 & $-9,03381$ & $-3,75167$ \\
\hline & & S-Score & $-4,855400^{*}$ & 1,115460 & ,000 & $-7,49647$ & $-2,21433$ \\
\hline \multirow[t]{6}{*}{ LSD } & Z-Score & S-Score & 1,537340 & 1,115460 & , 170 &,- 66707 & 3,74175 \\
\hline & & X-Score & $6,392740^{*}$ & 1,115460 & ,000 & 4,18833 & 8,59715 \\
\hline & S-Score & Z-Score & $-1,537340$ & 1,115460 & 170 & $-3,74175$ & ,66707 \\
\hline & & X-Score & $4,855400^{*}$ & 1,115460 & ,000 & 2,65099 & 7,05981 \\
\hline & X-Score & Z-Score & $-6,392740^{*}$ & 1,115460 & , 000 & $-8,59715$ & $-4,18833$ \\
\hline & & S-Score & $-4,855400^{*}$ & 1,115460 & ,000 & $-7,05981$ & $-2,65099$ \\
\hline
\end{tabular}

${ }^{*}$. The mean diff erence is significant at the .05 lev el.

Berdasarkan hasil olah data diperoleh nilai probabilitas One Way ANOVA Test antara X-Score dengan Z-Score maupun dengan S-Score $=$ $0,000<$ Level of Significant $=0,05$, maka disimpulkan bahwa terdapat perbedaan X-Score dengan Z-Score

\section{Pembahasan}

Dari ketiga model tersebut terdapat prosentase perbankan yang dikategorikan sehat, grey area, dan bangkrut. Hasil tersebut dapat dilihat pada tabel 4.10 sebagai berikut: maupun dengan S-Score. 
Tabel 9

Prosentase Perbandingan Tiga Model

Pada Bank Syariah di Indonesia tahun 2010-2014

\begin{tabular}{|l|r|r|r|}
\hline \multirow{3}{*}{ Kategori } & \multicolumn{2}{|c|}{ Prosentase Perbandingan Tiga Model } \\
\cline { 2 - 5 } & $\begin{array}{l}\text { Altman Z- } \\
\text { Score }\end{array}$ & $\begin{array}{l}\text { Springate S- } \\
\text { Score }\end{array}$ & $\begin{array}{l}\text { Zmijewski X- } \\
\text { Score }\end{array}$ \\
\hline Sehat & $20,00 \%$ & $62,00 \%$ & $72,00 \%$ \\
\hline Grey Area & $80,00 \%$ & - & \multicolumn{2}{|c|}{-} \\
\hline Bangkrut & - & $38,00 \%$ & $28,00 \%$ \\
\hline
\end{tabular}

Sumber: Data Diolah, 2016

Dari tabel 9 dapat diartikan bahwa:

1. Model Springate memprediksi bahwa 38,00 \% Bank Syariah berada dalam kategori bangkrut, dan $62,00 \%$ berada dalam kategori sehat.

2. Model Zmijewski memprediksi bahwa 28,00 \% Bank Syariah berada pada kategori bangkrut, dan $72,00 \%$ berada dalam kategori sehat.

3. Model Altman memprediksi bahwa 80,00 \% Bank Syariah berada pada kategori grey area, $20,00 \%$ berada dalam kategori sehat, dan tidak ada yang berada dalam kategori bangkrut.

Dari hasil diatas dapat disimpulkan bahwa Model Springate adalah model yang paling tepat untuk memprediksi bank syariah di Indonesia dengan akurasi 38,00\%, kemudian Model Zmijewski dengan tingkat akurasi 28,00 \% dan Altman dengan akurasi 0,00 \%. Hasil ini mendukung penelitian dari Sfarfina (2015) yang menyatakan bawha bank syariah tidak cocok menggunakan model Altman z-score original ataupun Altman z-score revisi. Hal ini karena kedua model Altman tersebut adalah model yang dibuat untuk memprediksi kebangkrutan dari perusahaan maufaktur baik yang sudah go public maupun yang belum.

\section{KESIMPULAN DAN SARAN Kesimpulan}

Berdasarkan hasil analisis menunjukan bahwa model Springate S-Score adalah model yang paling akurat untuk memprediksi kebangkrutan bank syariah di Indonesia.

\section{Saran}

1. Perbankan disarankan melakukan perubahan kebijakan strategik dalam komposisi modal dan akuisisi, sehingga memberikan hasil yang cukup efektif bagi perbankan untuk mengatasi kesulitan keuangan.

2. Bagi peneliti selanjutnya, disarankan menambah jumlah sampel atau periode penelitian, sehingga hasilnya lebih representatif terhadap keadaan yang sebenarnya dalam menilai kebangkrutan perbankan.

\section{Daftar Pustaka}

Amirullah. 2013. Metodelogi Penelitian Manajemen. Malang: Bayumedia Publising.

Atmini, S. dan Wuryan, A. 2005. Manfaat laba dan Arus Kas untuk Memprediksi Kondisi Financial Distress pada Perusahaan Textile Mill Products dan Appareal and 
Other Textile Products yang Terdaftar di Bursa Efek Jakarta. SNA VIII: hal 460474.

Darsono dan Ashari. 2005. Pedoman

Praktis Memahami Laporan

Keuangan. Edisi 1.

PenerbitIndeks: Jakarta.

F.Brigham, Eugene dan Joel

F.Houston. 2001. Manajemen

Keuangan. Edisi kedelapan.

Buku II Erlangga: Jakarta.

Pambekti, Galuh Tri. 2014. Analisis

Ketepatan Model Altman,

Springate, Zmijewski, Dan

Grover Untuk Prediksi

Financial Distress. Skripsi.

UIN Sunan Kalijaga.

Yogyakarta.

Pawito. 2009. Komunikasi Politik

Media Massa dan Kampanye

Pemilihan,

Yogyakarta: Jalasutra.

P.Tampubolon, Manahan. 2005.

Manajemen Keuangan

(Finance Management).

Ghalia Indonesia: Bogor.

Sinambela, Sarton. 2009. Prediksi

Kebangkrutan Perusahaan

Makanan Dan Minuman:

Dengan Pendekatan Metode

Altman Pada Perusahaan

Yang Tercatatdi Bursa Efek

Indonesia Periode 2003-

2007. Majalah Forum Ilmiah.

3(7). Fakultas Ekonomi

Universitas Mpu Tantular.

Subramanyam, K. R. \& Wild,

John. 2010. Analisis Laporan

Keuangan. Jakarta.

Sugiyono. 2011. Metode Penelitian

Kuantitatif, Kualitatif dan

$R \& D$. Bandung : Alfabeta

S.Munawir. 2002. Analisis Informasi

Keuangan.

Liberty

Yogyakarta: Yogyakarta.

Zu'amah, S. 2005. Perbandingan

Ketepatan Klasifikasi Model
Prediksi Kepailitan Berbasis Akrual dan Berbasis Aliran Kas. SNA VIII: hal 441-459. 
